\title{
The Paleocene-Eocene Thermal Maximum in Egypt and Jordan: An overview of the planktic foraminiferal record
}

\author{
Elisa Guasti* \\ Department of Geosciences (FB 5), Bremen University, Post Office Box 330440, 28334 Bremen, Germany \\ Robert P. Speijer \\ Department of Geography and Geology, Katholieke Universiteit Leuven, Celestijnenlaan, 200E, 3001 Leuven, Belgium
}

\begin{abstract}
In the present study, we investigate upper Paleocene to lower Eocene planktic foraminiferal assemblages in Egypt and Jordan across a middle neritic to upper bathyal transect of the Tethyan continental margin. In particular, we evaluate the planktic foraminiferal turnover across the Paleocene-Eocene Thermal Maximum (PETM). Dissolution affects the planktic assemblages more intensively than previously considered, especially in the marls below the PETM. High numbers of Subbotina, fluctuating planktic/benthic $(\mathrm{P} / \mathrm{B})$ ratios, and low numbers of planktic foraminifera per gram (PFN) are indicative of dissolution, probably as a consequence of deep weathering. Hence, high numbers of Subbotina in this area do not indicate cooling. Despite this taphonomic overprint, we observe that well-diversified planktic foraminiferal assemblages of Subzone P5a abruptly changed into oligotaxic assemblages dominated by Acarinina during the PETM. Because various biotic and geochemical proxies indicate increased nutrient supply to the basin, we argue that the blooming of Acarinina is not indicative of oligotrophic conditions. Instead, we postulate that (low-trochospiral) Acarinina may have been better adapted to thrive under stressed environmental conditions, possibly because they hosted symbionts different from those in Morozovella.
\end{abstract}

Keywords: PETM, planktic foraminifera, excursion taxa, Middle East.

\section{INTRODUCTION}

The Paleocene-Eocene Thermal Maximum (PETM) represents a period of extreme global warmth (Zachos et al., 1993), associated with a major extinction of deep-sea benthic foraminifera (Tjalsma and Lohmann, 1983; Thomas, 1998) and evolutionary rejuvenations among planktic foraminifera (Kelly et al., 1996b), mammals (Clyde and Gingerich, 1998), calcareous nannofossils

*Present address: Stratigraphy Group, Fugro Robertson Limited, Tyn-y-coed
Site, LL30 1 SA Llanrhos, Llandudno, North Wales, UK; elisag@ tiscali.co.uk.
(Aubry, 1998), diatoms (Oreshkina and Oberhänsli, 2003), and larger foraminifera (Scheibner et al., 2005). Accompanying this interval is a negative $2 \%$ - $3 \%$ carbonate isotopic excursion (CIE) (Kennett and Stott, 1991; Koch et al., 1995). What triggered the event is still under debate. The most widely accepted idea is that initial deep-sea warming led to the massive dissociation of oceanic methane hydrates, leading to further warming (Dickens et al., 1995). Other theories involve an increase of volcanic emission (Eldholm and Thomas, 1993), cometary impact (Kent et al., 2003), or intrusion of mantle-derived melts into carbon-rich sediments in the northeast Atlantic (Svensen et al., 2004).

Guasti, E., and Speijer, R.P., 2007, The Paleocene-Eocene Thermal Maximum in Egypt and Jordan: An overview of the planktic foraminiferal record, in Monechi, S., Coccioni, R., and Rampino, M., eds., Large Ecosystem Perturbations: Causes and Consequences: Geological Society of America Special Paper 424, p. 53-67, doi: 10.1130/2007.2424(03). For permission to copy, contact editing@ geosociety.org. @2007 The Geological Society of America. All rights reserved. 
It is also heavily debated whether this "supergreenhouse" period was generally associated with increased or decreased oceanic productivity. Several oceanic records and particularly the calcareous nannofossils suggest widespread oligotrophy (Kelly et al., 1996b; Bralower, 2002). In contrast, most continental-margin records suggest an increase in productivity (Speijer et al., 1996b, 1997; Schmitz et al., 1997b; Crouch et al., 2001; Speijer and Wagner, 2002; Gavrilov et al., 2003) and also some open-ocean records provide evidence for this (e.g., Thompson and Schmitz, 1997; Bains et al., 2000; Thomas et al., 2000; Stoll and Bains, 2003). An overall increase in oceanic productivity and burial of organic carbon in marine sediments would provide an important negative feedback mechanism (Bains et al., 2000; Dickens, 2001; Speijer and Wagner, 2002). Bains et al. (2000) suggested that an increase in nutrient supply may have caused blooms in marine phytoplankton, thereby sequestering the greenhouse gas $\mathrm{CO}_{2}$ to the deep sea by $\sim 60$ k.y. of enhanced biological pumping. This bloom might have been a response to a combination of increased weathering and runoff from the continents, oceanic fertilization from volcanic fallout, rising temperatures, and increasing atmospheric $\mathrm{CO}_{2}$ concentrations (Bains et al., 2000, and references therein).

The southern Tethyan margin is of particular interest for studying lower Paleogene continental-margin records, as it provides continuously well-exposed outcrops and well-preserved material for micropaleontological research. For these reasons, the global boundary stratotype section and point (GSSP) for the Paleocene-Eocene boundary has recently been defined in Egypt within the Dababiya Quarry section, near Luxor in the Nile Valley (Ouda and Aubry, 2003).

The PETM in Egypt has been intensively investigated mainly on the basis of smaller benthic foraminifera (Speijer, 1994; Speijer et al., 1996a, 1996b, 1997; Youssef, 2004; Alegret et al., 2005; Ernst et al., 2006), larger benthic foraminifera (Scheibner et al., 2005), planktic foraminifera (Obaidalla, 2000; Berggren and Ouda, 2003; Ouda et al., 2003), nannoplankton (Aubry et al., 1996; Monechi et al., 2000, Tantawy et al., 2003; Youssef, 2004), ostracodes (Speijer and Morsi, 2002; Elewa and Morsi, 2004), and geochemical and mineralogical parameters (Charisi and Schmitz, 1995, 1998; Schmitz et al., 1996, 1997b; Bolle et al., 2000; Speijer and Wagner, 2002; Dupuis et al., 2003; Knox et al., 2003).

In this study, we evaluate planktic foraminifera assemblages, along a middle neritic to upper bathyal transect, from exposures in Egypt (Nile Valley, Eastern Desert, and Sinai) and in Jordan (Fig. 1). They are situated in an extensive epicontinental basin that covered most of Egypt, Israel, and Jordan at the end of the Paleocene (Speijer and Wagner, 2002), generally deepening in a northwest direction. The area is characterized by two major tectonic provinces, the stable shelf in the south (also known as the Nile Basin) and the unstable shelf in the north (Syrian Arc) (Said, 1990; Shahar, 1994; Tawarados, 2001). The localities studied in this work belong to the stable shelf (Said, 1990). Benthic foraminiferal data indicate that shallowest deposition occurred at Gebel Duwi (middle neritic, 50-100 $\mathrm{m}$ ) and the deepest at Wadi Nukhl (upper bathyal, 500-600 m) (Speijer et al., 2000). Gebels

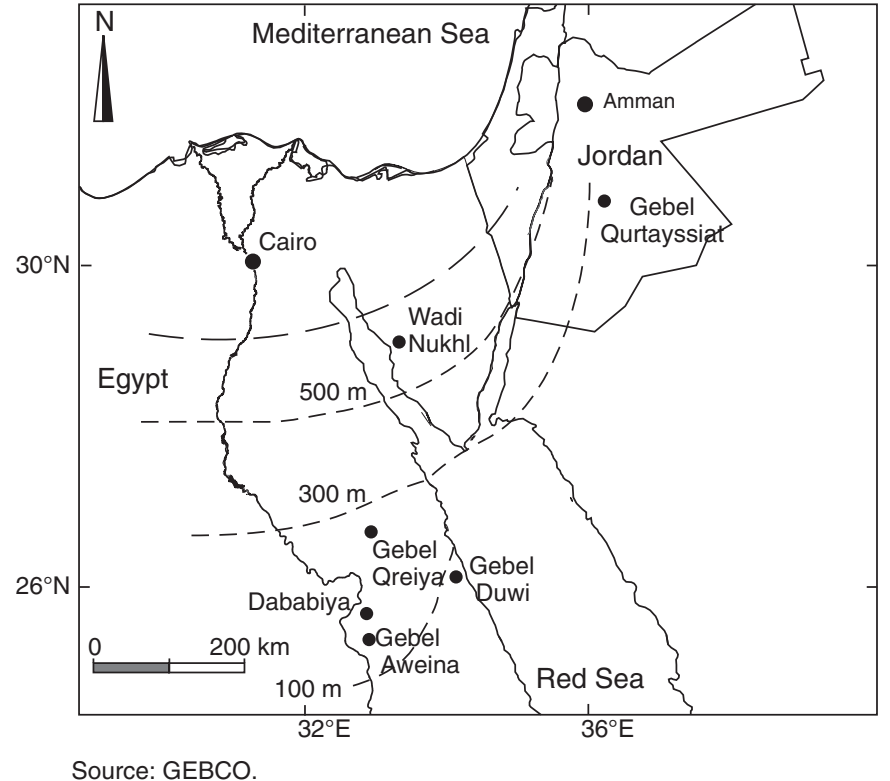

Figure 1. Location map of the studied profiles (black dots). During the Neogene, the Jordanian localities shifted $\sim 100 \mathrm{~km}$ north in response to sinistral movements along the Dead Sea transform fault (DST) (Garfunkel and Ben-Avraham, 1996). The normal dashed lines indicate the estimated paleobathymetry based on Speijer and Van der Zwaan (1994). The thick dashed line separates the stable shelf (south) from the unstable (north part).

Aweina, Qreiya, Dababiya, and Qurtayssiat represent outer neritic localities with paleodepths between 150 and $200 \mathrm{~m}$.

This transect provides a good opportunity to document the planktic foraminiferal developments across the PETM. Planktic foraminifera assemblages dominated by Acarinina characterize the PETM in open-marine environments worldwide. This has been interpreted as an indication of oceanic oligotrophy (Kelly et al., 1996b, 1998). However, we consider it highly unlikely that oligotrophic conditions of the open ocean could also prevail on the Tethyan margin, where, by contrast, all other proxies suggest an increase of nutrients and/or productivity. Therefore, we reevaluate previous paleoecological interpretations of this typical PETM planktic foraminifera assemblage.

\section{MATERIAL AND METHODS}

We collected samples at six locations. For Gebel Qreiya, Wadi Nukhl, and Gebel Qurtayssiat we used low-resolution sample sets ( 1 m). For Duwi and Aweina centimeter scale sample sets across the PETM were available. Samples of the Dababiya DBH section, a 6-m-thick section comprising the GSSP of the Paleocene-Eocene boundary, were kindly provided by Christian Dupuis (Polytechnic of Mons). In order to further enhance the resolution of the Dababiya DBH record, we collected additional samples on the occasion of the inauguration of the GSSP of the P-E boundary during the Climate and Biota of the Early Paleo- 
gene conference (CBEP IV) in Luxor, 2004. In the Dababiya and Qreiya sections, the P-E boundary is well defined at the basis of a non-calcareous clay to siltstone (Dupuis et al., 2003; Knox et al., 2003). In the Aweina section, the P-E boundary is situated at an omission surface between the shaley marls of Esna unit 1 and the overlying more limey ("calcarenitic") bed. Abundant bioturbations extend some $7 \mathrm{~cm}$ down from the latter bed into the underlying shaley marls, indicating the absence of the lower PETM beds (Speijer et al., 1996a; Schmitz et al., 1997b).

All samples were processed according to standard micropaleontological procedures explained by Speijer et al. (1996b) (samples from Egypt) and by Guasti (2005) (samples from Jordan). The fraction $>125 \mu \mathrm{m}$ was used for all foraminiferal studies. We determined compositional data of the planktic foraminiferal assemblages, counting 200-300 specimens classified at genus level, generally using the concepts of Berggren and Norris (1997) and Olsson et al. (1999). In addition, we calculated the percentage of planktics in the foraminiferal association (planktic/benthic, or $\mathrm{P} / \mathrm{B}$, ratio, expressed as $100 \mathrm{xP} /(\mathrm{P}+\mathrm{B})$ (cf. Van der Zwaan et al., 1990), as well as the total number of planktic foraminifera per gram of dry sediment (PFN) were calculated in order to identify taphonomic alteration of the foraminiferal assemblages.

Carbonate content and whole-rock stable isotopes $(\mathrm{O}, \mathrm{C})$ were measured for the Qurtayssiat section at the Free University of Amsterdam (see Table 1). These parameters have been presented for the other sections in earlier studies (Speijer et al., 1996a; Schmitz et al., 1996; Speijer and Wagner, 2002; Dupuis et al., 2003).

\section{STRATIGRAPHY}

\section{Lithostratigraphy}

In the Nile Valley and Eastern Desert (Egypt) the upper Paleocene to lower Eocene marls and shales belong to the Esna Formation, which is intercalated between the limestones of the upper Paleocene Tarawan Formation and the lower Eocene Thebes Formation (Said, 1990). In Sinai, the Tarawan Formation is often absent; therefore, the entire Paleocene to lower Eocene succession is often referred to as the Esna Formation (see details in Scheibner et al., 2001). Stratigraphy of the Duwi, Aweina, and Qreiya sections were discussed extensively by Speijer et al. (2000), the Dababiya section by Dupuis et al. (2003). We tenta-

TABLE 1. CARBONATE CONTENT AND CARBONATE ISOTOPIC RECORD FROM GEBEL QURTAYSSIAT

\begin{tabular}{lcccr}
\hline \hline Profile & Sample & $\begin{array}{c}\text { Level } \\
(\mathrm{m})\end{array}$ & $\begin{array}{c}\mathrm{CaCO}_{3} \\
(\%)\end{array}$ & \multicolumn{1}{c}{$\begin{array}{c}\delta^{13} \mathrm{C} \\
(\%)\end{array}$} \\
\hline Gebel Qurtayssiat, JQ & 68 & 64 & 75.17 & -2.14 \\
& 67 & 63.2 & 48.86 & 0.29 \\
& 66 & 62.5 & 56.94 & -0.27 \\
& 65 & 61.9 & 50.01 & -1.92 \\
& 64 & 61.1 & 39.54 & -2.19 \\
& 63 & 60.5 & 56.34 & -0.18 \\
& 62 & 59.8 & 60.81 & 1.11 \\
\hline
\end{tabular}

tively adopt the lithostratigraphic subdivision of the lower part of the Esna Formation as proposed by Dupuis et al. (2003) for the Dababiya section and applied to the Qreiya section by Knox et al. (2003) (Fig. 2). This subdivision consists of Esna unit 1, ranging from the top of the Tarawan Formation to the base of the PETM beds, known in the Nile Valley as the Dababiya Quarry Beds. Esna unit 1 consists of gray shaley marls. Esna unit 2 comprises the Dababiya Quarry beds and the overlying gray shales and marly shales. In full expression, the Dababiya Quarry Beds are composed of a succession of five different beds with an upward-increasing carbonate content. At the base, DQB1 is a dark, laminated non-calcareous clay without calcareous foraminifera, whereas at the top, DQB5 is a calcarenitic marl, largely composed of foraminifera. The middle part of the Dababiya Quarry beds, particularly DQB3 and the top of DQB2, is rich in apatite, largely in the form of coprolites and fish remains. The Paleocene-Eocene boundary coincides with the base of the clay bed of DQB1 (1.56 $\mathrm{m}$ above the base of the DBH section) at Dababiya (Dupuis et al., 2003). In addition to the sharp contact from marl to shale, it is characterized by a pronounced shift in $\delta^{13} \mathrm{C}$ of organic carbon, thus providing an excellent tool for correlation with deep-sea and terrestrial records spanning the P-E transition. The bio- and chemostratigraphy of these Egyptian localities were documented by Speijer et al. (2000) and Speijer and Wagner (2002). These authors pointed out that at Qreiya and Wadi Nukhl a dark-brown marl bed rich in total organic carbon (TOC), coprolites, fish bones and scales, and foraminifera marks the onset of the PETM. According to the criteria of Wignall (1994) this bed qualifies as black shale and was denoted as such. This bed was not observed at Aweina, thus pointing to an unconformity across the P-E boundary in this section.

Evaluation of results from Egypt in the context of the detailed Dababiya and Qreiya sequence (Dupuis et al., 2003; Knox et al., 2003) indicates that the coprolite-rich, dark-brown marl bed ("black shale") observed at Qreiya (Speijer et al., 2000; Speijer and Wagner 2002) corresponds to DQB3. Consequently, this bed does not correspond to the true onset of the PETM, as considered earlier, but rather to the level with minimum $\delta^{13} \mathrm{C}$ values and thus a somewhat later stage during the PETM (Dupuis et al., 2003).

In Wadi Nukhl, Qreiya, and Qurtayssiat the low-resolution sampling might be the main cause for not identifying all DBQ beds in our records (mainly DBQ1-2 are absent from our data set). Recent studies on Qreiya by (Knox et al., 2003; Berggren and Ouda 2003; Soliman 2003) and new field observations indicate that this is true at least for the Qreiya section.

Over a large area in Egypt, DQB5 is the most distinct bed within the relatively monotonous Esna succession, especially in weathered outcrops, because in all sections it has anomalously high $\mathrm{CaCO}_{3}$ content $(50 \%-70 \%)$ in the lower part of the Esna Formation. This bed corresponds to the bed previously denoted as Esna unit C at Aweina (Speijer et al., 1996b) and more generally as the "calcarenitic bed" (Schmitz et al., 1997b; Speijer et al., 2000) because of its enormous abundance of planktic foraminifera $(>10,000$ specimens/gram in the size fraction $>125$ 


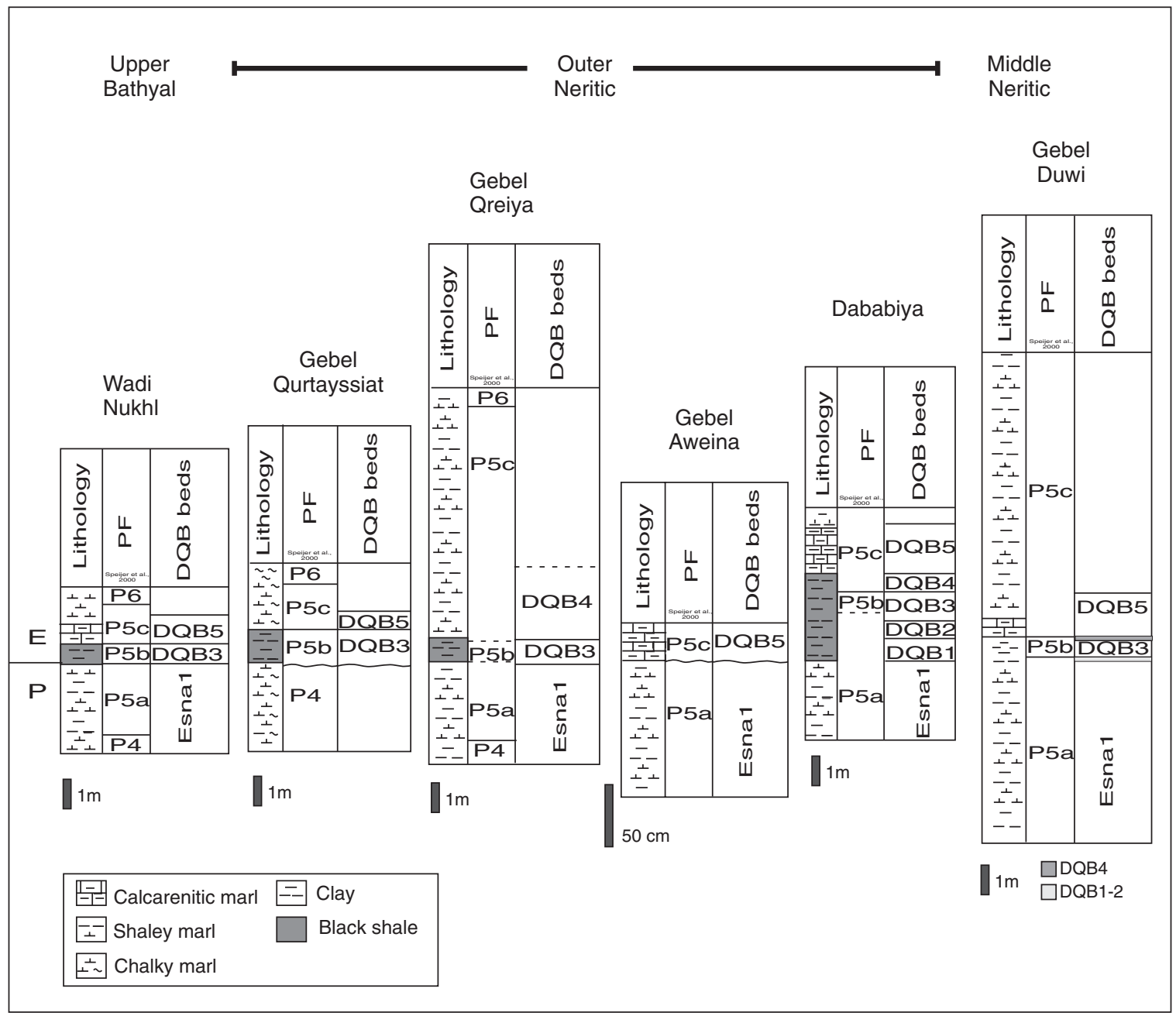

Figure 2. Stratigraphic correlation of the localities, arranged along a transect from the deeper localities on the left to the shallowest ones on the right (roughly a N-S orientation). Planktic foraminiferal biostratigraphy follows Speijer et al. (2000); Gebel Aweina has been vertically exaggerated. DQB-Dababiya Quarry beds.

microns). This bed records the return to more positive $\delta^{13} \mathrm{C}$ values (Schmitz et al., 1997b; Speijer et al., 2000; Dupuis et al., 2003). At Aweina, this equivalent to DQB5 directly overlies Esna 1. Thus DQB1-4 were either not deposited or not preserved at Aweina, marking a significant hiatus at the P-E boundary (Speijer et al., 2000).

Ouda et al. (2003) provided a strongly deviating interpretation of the stratigraphic sequence across the P-E boundary at Aweina. These authors suggested that a 1-m-thick interval below the calcarenitic bed records the onset of the carbon isotope excursion (CIE). These beds would thus correlate with the lower Dababiya Quarry Beds and instead the upper ones would be missing. The isotopic data consulted for this view were derived from the data presented by Charisi and Schmitz (1995) and Schmitz et al. (1996). However, these and other authors, including Ouda (2003), convincingly demonstrated that $\delta^{13} \mathrm{C}$ records based both on whole rock and Lenticulina spp. show virtually straight verti- cal lines up to the unconformity, i.e., the base of the calcarenitic bed (Schmitz et al., 1996, 1997b; Speijer et al., 1996a, 2000; see also Figs. 2, 4, and 7, in Ouda, 2003). These values, 1\% for whole rock and around $-1 \%$ o for Lenticulina spp., fit well within the range of pre-PETM values elsewhere in the region and are much higher than values $(-1 \%$ o to $-2 \%$ ) for whole-rock measurements found within the PETM in the region (e.g., Speijer et al., 2000). If the view of Ouda et al. (2003) were correct, the Aweina record should show a negative excursion below the calcarenitic bed (DQB5), followed by an abrupt positive shift at the unconformity. The opposite in fact is true: there is no shift below the unconformity and a small negative shift above it. Biostratigraphic data, such as the presence of Acarinina sibaiyaensis and A. africana just below the unconformity (Ouda et al., 2003), cannot be considered as evidence for the opposite view, because these taxa were originally described from the top of the Tarawan Formation and from Esna unit 1 (El-Naggar, 1966; Speijer et al., 2000). Thus 
we are confident that the deposits immediately underlying DQB5 at Aweina constitute the top of the Paleocene of Esna 1 unit, not the base of the Eocene. Consequently also the correlation of the P-E boundary at Aweina to other Nile Valley sections, such as G. Kilabiya, G. Qreiya, and Abu Ghurra (Berggren et al., 2003; Ouda and Berggren, 2003; Ouda et al., 2003), needs revision.

In Gebel Duwi, the lithostratigraphic equivalent to DQB3 developed somewhat differently from Dababiya and Qreiya as a 20-cm-thick fissile pink marl, containing abundant phosphatic peloids and fish remains (Speijer et al., 2000). Underneath this bed, Speijer et al. (2000) observed a 1-cm-thick shale bed without foraminifera, overlying a 20 -cm-thick reddish interval with abundant calcitic pseudomorphs of dolomite rhombs and few foraminifera. It is not unlikely that this interval could in part correspond to DQB1-2. Similar to Gebel Aweina and Wadi Nukhl, a calcarenitic bed, correlative with DQB5, is present in the upper part of the CIE. From our data it is not clear whether an equivalent to DQB4 is present at Duwi or not.

In Jordan the studied interval belongs to the pale yellow, light-gray chalky and marly sediments, which have been named Muwaqqar Chalk Marl Formation (MCM) by Masri (1963). Like the Esna Formation in Egypt, the MCM is rich in secondary gypsum veins. It is overlain by the chert-rich chalky limestones of the Umm Rijam Chert Limestone Formation. Within the monotonous marly MCM sediments, a 1-m-thick dark-purple bed, partially laminated and rich in fish remains, is intercalated. Lithological and sedimentological similarities and biostratigraphic data suggest that this bed correlates with DQB3.

\section{Biostratigraphy}

The studied interval belongs to planktic foraminifera Zone P5 (Berggren et al., 1995), defined as the biostratigraphic interval between the Last Appearance Datum (LAD) of Globanomalina pseudomenardii and the LAD of Morozovella velascoensis. We apply a subdivision (Subzones P5a-P5c) proposed by Speijer et al. (2000), which consists of three subzones: Subzone P5a or Globanomalina chapmani Interval Subzone, Subzone P5b or Morozovella allisonensis Total Range Subzone, and Subzone P5c or the Globanomalina luxorensis Interval Subzone. Subzone P5b was originally considered to represent the early part of the PETM. Morozovella allisonensis is common and well preserved in deposits equivalent to DQB3 at Qreiya and Gebel Duwi. We have also observed it in our samples from Nukhl, Dababiya, and Qurtayssiat, in DQB3, though it is not common. According to Berggren et al. (2000) and Berggren and Ouda (2003), the application of this scheme has been problematic, because M. allisonensis occasionally occurs too sporadically. Instead, Berggren and Ouda (2003) favored the range of the more common A. sibaiyaensis to characterize a subzone correlative with the PETM. However, it has been demonstrated that the subbiozonation of Zone P5 based on the occurrence of Acarinina sibaiyaensis leads to miscorrelations, because this taxon, together with A. africana, occurs well before the PETM (El-Naggar 1966;
Speijer et al., 2000; Norris and Nunes, 2004; Guasti, 2005). This results mainly from taxonomic ambiguities, but these need to be resolved prior to introducing a formal subzonation of Zone P5. Hence, until these ambiguities are clarified we prefer the use of Subzone P5b based on the occurrence of M. allisonensis, which thus far has been observed exclusively within the PETM (Kelly et al., 1996b, 1998; Speijer et al., 2000). Subzone P5b marks DQB3 in every locality. Within the high-resolution context of Dababiya this subzone represents the middle part of the CIE, i.e., the level where $\delta^{13} \mathrm{C}$ values reach minimum values and start to increase again to a level midway the gradual return to stable values.

In Gebel Qurtayssiat, the black shale (DQB3) contains a calcareous nannofossil assemblage indicative of CP8b of Okada and Bukry (1980), based on the first occurrence of Rhomboaster (in particular R. calcitrapalbitrifida, R. cuspis, and R. spineus). This bed immediately overlies marls corresponding to Zone CP4, indicating the presence of an expanded hiatus (Eliana Fornaciari, 2004, personal commun.). The planktic foraminiferal assemblages, just below the PETM, record an interval of strong dissolution (probably in Zone P4).

\section{RESULTS}

\section{Planktic Foraminiferal Assemblages}

The planktic foraminiferal assemblages in the study area are composed mainly of Acarinina, Morozovella, and Subbotina, which together made up $>80 \%$ (Fig. 3). Igorina, Parasubbotina, and Globanomalina are generally $<5 \%$. Chiloguembelina and Zeauvigerina always occur in background numbers $(<1 \%)$.

\section{Pre-PETM}

In the marls below the PETM, Subbotina exhibits maximum values: $13 \%-27 \%$ at Duwi, $~ 30 \%$ at Dababiya, and up to $\sim 40 \%$ at Aweina and Wadi Nukhl. A maximum of $62 \%$ is recorded at Qreiya. At Nukhl, Globanomalina is present in higher numbers $(\sim 7 \%)$ compared to the other localities. Among the surface dwellers, Morozovella is the most abundant genus and it ranges from a minimum value at Qreiya (12\%), 40\% at Nukhl, to a maximum at Duwi $(\sim 60 \%)$. At Duwi, the abundance of Igorina is slightly higher than in the others localities (up to $8 \%$ ). Acarinina makes up $27 \%$ in Duwi and Qreiya and $\sim 20 \%$ in Nukhl. At Aweina a maximum abundance of Acarinina $(\sim 50 \%)$ occurs just underneath the unconformity at the P-E boundary, where Morozovella decreases to $28 \%$. Striking is the common occurrence of $A$. sibaiyaensis and A. africana in the uppermost $50 \mathrm{~cm}$ of the Paleocene at Aweina.

$\mathrm{P} / \mathrm{B}$ ratios, expressed as $\% \mathrm{P}$, generally fluctuate between $35 \%$ and $75 \%$ at Aweina and Dababiya (Fig. 4). Just underneath the unconformity at the P-E boundary at Aweina, a peak of $97 \%$ is sandwiched between two lower values (45\% below and $25 \%$ above). The values are more constant at Nukhl $(\sim 75 \%)$ and Duwi ( $65 \%)$. At Qreiya a minimum value $(6 \%)$ is recorded at the base of Esna unit 1. 


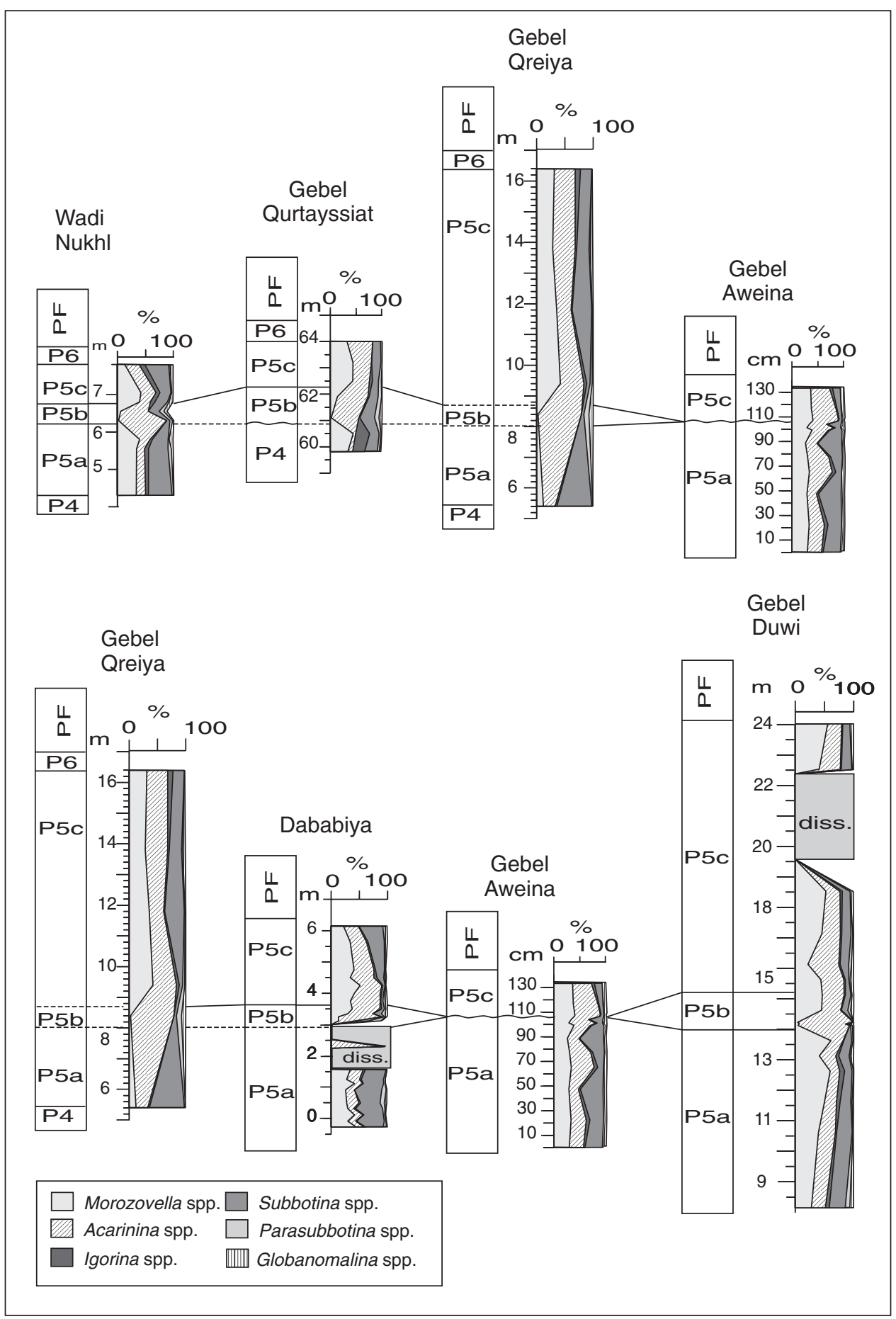

Figure 3. Relative frequency of planktic foraminiferal assemblages. Planktic foraminiferal biostratigraphy follows Speijer et al. (2000); Gebel Aweina has been vertically exaggerated. 


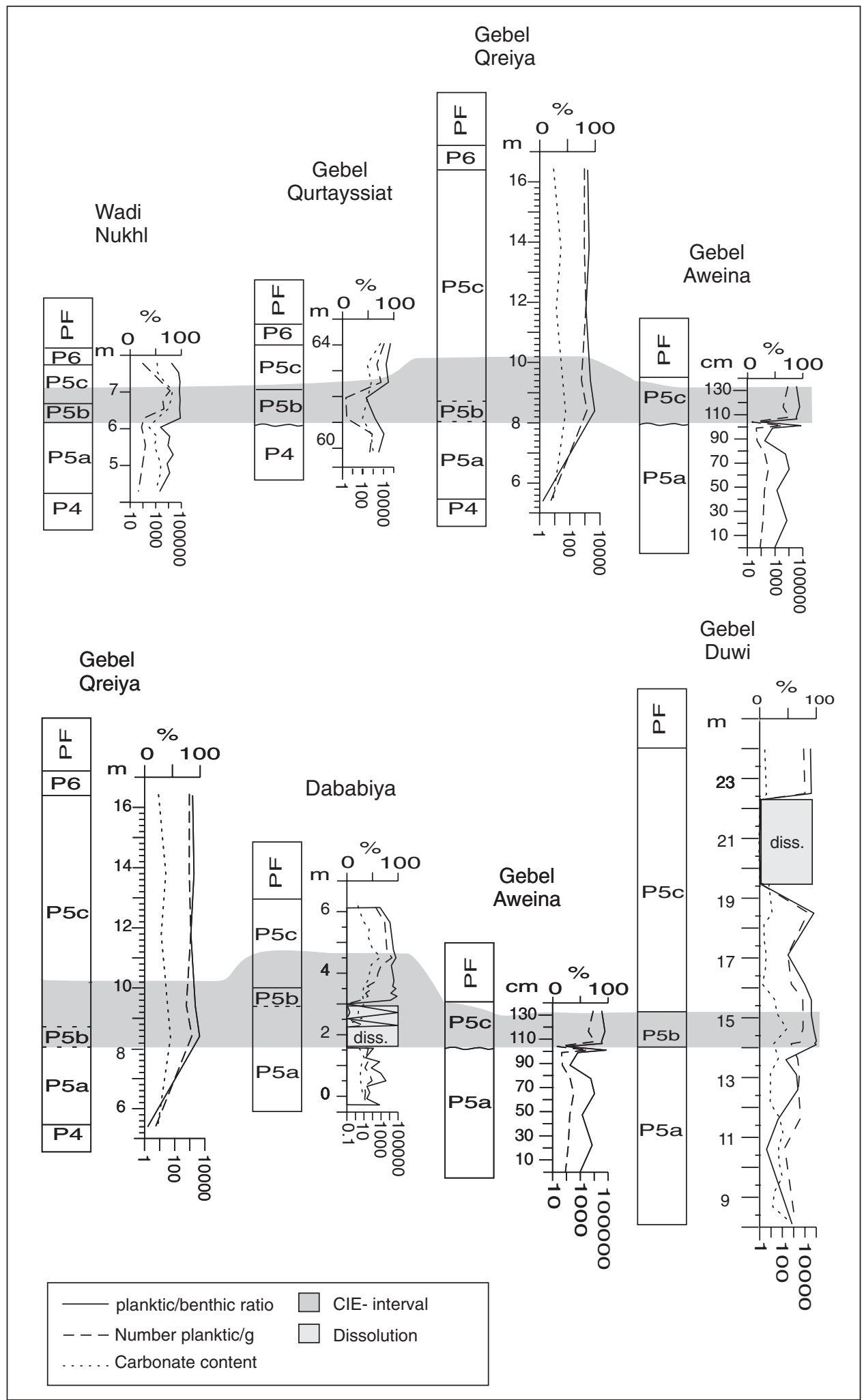

Figure 4. Planktic/benthic ratio (\%P), the numbers of planktic foraminifera/gram (PFN) expressed as logarithmic scale and the carbonate content $\left(\mathrm{CaCO}_{3 \%}\right)$. Planktic foraminiferal biostratigraphy follows Speijer et al. (2000); Gebel Aweina has been vertically exaggerated. CIE indicates the carbonate isotopic excursion. 
Planktic foraminiferal numbers (PFN) range between 150 and 4500 at Duwi (Fig. 4). At Aweina, Nukhl, and Dababiya these numbers are lower, between 20 and 300. At Qreiya the lowest value is recorded at the base of Esna unit 1; only five planktic specimens per gram.

Pre-PETM beds contain $40 \%-50 \% \mathrm{CaCO}_{3}$ at Duwi, Dababiya, and Nukhl, and $30 \%$ in Aweina. Just below the PETM, the values decrease to $\sim 35 \%$ at Nukhl and $20 \%$ at Qreiya.

From these data we observe that depressed P/B ratios, lower PFNs, and low carbonate contents correspond with high numbers of Subbotina, in samples relatively rich in oxidized pyritic burrow fills.

\section{PETM}

A major change in the planktic foraminiferal assemblages occurs within the lower part of the PETM. In beds DQB1-2 at Dababiya, no planktic foraminifera are present, except for a relative peak of poorly preserved Acarinina ( 90\%) in sample DBH 2.3 (bed DQB2), in which a multichambered variety of Acarinina sibaiyaensis also is recorded. At Duwi these beds possibly correspond to $1 \mathrm{~cm}$ shale and the underlying dolomitic interval $(\sim 20 \mathrm{~cm})$. In the other localities these beds are not recorded in our sample sets. Instead, DQB3 and equivalent beds can be traced in all sections except Aweina and are characterized by very high numbers of Acarinina ( 80\%). In Qurtayssiat, Acarinina is slightly less abundant ( 60\%), and Subbotina, Parasubbotina, and Globanomalina exhibit higher values $(30 \%, 7 \%$, and $6 \%$, respectively), compared to the other sections. In this interval $M$. allisonensis and a multichambered variety of Acarinina sibaiyaensis are recorded, of which the latter is the major component. Acarinina sibaiyaensis (sensu El-Naggar, 1966) and A. africana also occur, but in low numbers. At Dababiya in sample DBH 3.12 Acarinina decreases $(\sim 30 \%)$ and Parasubbotina reaches a maximum ( $21 \%)$.

Maximum P/B ratios $(>99 \%)$ are encountered at Wadi Nukhl, Duwi, and Qreiya, whereas in Gebel Qurtayssiat the P/B ratios decrease $(\sim 64 \%)$. In DQB2, just one sample, DBH 2.3, contains enough foraminifera to have a reliable $\mathrm{P} / \mathrm{B}$ ratio: its $\mathrm{P} / \mathrm{B}$ ratio is $\sim 100 \%$, whereas sample DBH 2.72 contains only ten planktic foraminifera in the whole residue.

Planktic foraminiferal numbers of the lower PETM beds vary between the sections, but they are generally higher than in the marls below. At Dababiya these values are $<10$ in DQB2-lower DQB3 and they increase up to 100 in upper DQB3. These numbers are up to 3700 at Duwi, $\sim 1400$ at G. Qreiya, and $\sim 300$ at Wadi Nukhl. Only at Qurtayssiat the value is extremely low $(\sim 2 / \mathrm{g})$.

At Dababiya, at the base of DQB1 the carbonate content drops to zero, increasing from the lower part of DQB2 upward. From sample DBH 2.5 onward the values increase again to $30 \%$. In DQB3 and equivalents at Dababiya, Duwi, and Qurtayssiat, the carbonate content is generally $\sim 40 \%$, and $\sim 50 \%$ at Qreiya and Wadi Nukhl.

In DQB4-5, above the interval of Acarinina dominance, the planktic foraminiferal assemblages become more diversified, as indicated by the gradual decrease of Acarinina, and the increase of the other genera. Specimens of A. sibaiyaensis and A. africana are rarely found in DQB4-5 at Dababiya and Aweina, and neither $M$. allisonensis nor a multichambered variety of Acarinina sibaiyaensis occur anymore. Overall, Morozovella ranges from $36 \%$ to $46 \%$ and Subbotina increases, but the values remain lower than in Subzone P5a (6\%-17\% at Duwi and Aweina). In Aweina and Duwi, Globanomalina is more common $(<4 \%$ and $<6 \%$, respectively) than in Subzone P5a.

The $\mathrm{P} / \mathrm{B}$ ratios in DQB4-5 increase up to 80\%-95\% and the values are fairly constant in each locality. Similarly, the PFNs abruptly increase, between 10,000 (at Aweina) and 15,000 (at Dababiya and Duwi). At Qreiya the numbers are lower, 1200 (DQB4). Also the carbonate contents increase in DQB4-5, ranging from 50\% at Aweina, to $>60 \%$ at Dababiya and $>80 \%$ at Nukhl.

\section{Post-PETM}

Above DQB5, in the post-PETM phase, planktic foraminiferal assemblages continue to diversify in all localities. At Dababiya and Nukhl, Morozovella decreases toward the uppermost part with minimum values on top $(21 \%$ and $12 \%$, respectively), whereas Subbotina increases (up to $42 \%$ in both localities).

An opposite trend is observed in Qreiya, where Subbotina decreases and Morozovella increases upward. Numbers of Acarinina are $30 \%$ in Nukhl and Dababiya, higher in Qreiya and Duwi ( 40\%), and 40\% or more in Gebel Qurtayssiat.

Generally the P/B ratios are quite stable between $85 \%$ and $90 \%$, slightly higher in Nukhl (>90\%). The numbers of foraminifera are generally quite stable $\sim 1000 / \mathrm{g}$, with a maximum peak in Duwi $(\sim 18,000 / \mathrm{g})$ and a minimum in Nukhl $(\sim 90 / \mathrm{g})$. Generally, the carbonate content values are quite stable around $30 \%$, but in Nukhl they are higher ( 50\%). At Duwi, on the other hand, from sample 1033 onward, an interval with lower carbonate content $(\sim 20 \%)$ is recorded, interrupted by a $\sim 1.5$-m-thick interval with no carbonate between samples 1040 and 1042 .

\section{DISCUSSION}

\section{Avoiding Taphonomic Pitfalls}

The paleoecological significance of foraminiferal assemblages is based on the assumption that the fossil assemblage is a good reflection of the original live assemblage. However, the original ecological assemblage is transformed by a number of processes, of which differential test production (population dynamics) and preservation (taphonomy) are the most important ones (Martin, 1993). Processes of population dynamics are difficult to reconstruct in past environments and especially for extinct taxa. Taphonomic distortion of the assemblages is more easily identified (see below) and often is linked to the depositional environment (Loubere and Gary, 1990; Martin, 1993). Despite the transformation from the live assemblage to the dead assemblage, the fossil foraminiferal assemblage still con- 
tains important and detailed information of the (time-averaged) environmental conditions during deposition (e.g., Jorissen and Wittling, 1999; Murray and Alve, 1999).

Dissolution of calcareous tests below the lysocline is a welldocumented and understood phenomenon in deep-sea oceanography and paleoceanography (e.g., Berger, 1970). Dissolution, however, is not exclusively restricted to the deep-sea. Partial or complete carbonate dissolution is also sometimes encountered in shallow marine deposits exposed on land. This process may occur during deposition in undersaturated (e.g., brackish) waters, during diagenetic alteration (e.g., with the formation of carbonate concretions), and under the influence of weathering (El Kammar and El Kammar, 1996). In addition, the metabolic consumption of organic carbon from benthic organisms within sediments may contribute to dissolution of calcite even above the lysocline (Freiwald, 1995; Dittert et al., 1999). Dissolution may also occur during sample processing in the laboratory, for instance if sediment containing pyrite-filled tests is disintegrated with the aid of an $\mathrm{H}_{2} \mathrm{O}_{2}$ solution. Besides the potentially mechanically destructive bubbling from an $\mathrm{H}_{2} \mathrm{O}_{2}$ inside foraminifera tests (e.g., Hodgkinson, 1991), dissolution can be a serious problem: the rapid oxidation of pyrite leads to the formation of sulfuric acid, lowering the $\mathrm{pH}$ of the solution within the tests. In this way, pyritefilled tests will partially or fully dissolve. The effect is similar to long-term weathering of pyrite-filled tests in outcrops. In studies on microfossil assemblages from continental-margin deposits, partial dissolution is an often ignored problem. The problem becomes apparent when, for instance, the $\mathrm{P} / \mathrm{B}$ ratio is used as an indication for paleodepth and sea-level change. It is well known that tests of planktic foraminifera are generally more susceptible to dissolution than those of hyaline benthic foraminifera (Douglas and Woodruff, 1981). Moreover, in the modern ocean the more solution-susceptible planktic foraminifera species are relatively small in size and have large pores and thin walls, whereas the less solution-susceptible species have large tests with small pores and thick walls, and, in general, spinose species are less resistant than the non-spinose ones (Bé, 1977).

Moreover, Paleocene planktic foraminifera appear to have dissolved differentially, as pointed out by Boersma and Premoli Silva (1983). These authors constructed a solution-susceptibility ranking for planktic genera, in environments presumably below the foraminiferal lysocline. In order of decreasing susceptibility: the juveniles of most groups, the large morozovellids, acarininids, small morozovellids, smooth-walled genera, Parasubbotina and Subbotina (spinose taxa). Dissolution during diagenesis is probably controlled more by wall thickness and it acts first on smaller and thinner forms than on more robust taxa, and thus morozovellids are the most resistant ones (Boersma and Premoli Silva, 1983).

There are further ways to assess the amount of dissolution in foraminiferal assemblages. For instance, planktic/benthic ratios can be evaluated against the total number of foraminifera per gram of sediment (PFN). The amount of $\mathrm{CaCO}_{3}$ in the sediment provides additional information. Where fluctuations between these records coincide, e.g., a drop in $\mathrm{P} / \mathrm{B}$ ratio together with a drop in $\mathrm{PFN}$ and $\mathrm{CaCO}_{3}$, it is likely that carbonate dissolution has occurred at some step during the generation of the fossil assemblage (e.g., Speijer and Schmitz, 1998). In exceptional situations this association of changes may indicate a real paleoenvironmental change. If so, in shelf settings this should be readily discernable from the composition of a well-preserved planktic and/or benthic foraminiferal assemblage.

Moreover, weathering in arid regions deeply affects the composition of the sediments. El Kammar and El Kammar (1996), in their study on the shales and marls of the Campanian to Paleocene Duwi and Dakhla Formations in Egypt, established that the total organic carbon (TOC) of these units diminishes dramatically upon weathering (from an average $7.05 \%$ to $0.04 \%$ ). At the same time, the content of calcite is also drastically reduced by $\sim 60 \%$, owing to the carbonic acid produced as organic matter decays during weathering. Therefore, the increase of clay content is only apparent, deriving probably from a depletion of carbonate and organic matter contents. El Kammar and El Kammar (1996) also showed that fresh TOC-rich samples of the Dakhla Formation in the Eastern Desert could only be obtained from caves, not from normal exposures prone to weathering. Speijer and Wagner (2002) and Speijer (2003) measured TOC contents in the Esna and Dakhla Formations, respectively. Beyond the PETM, the TOC content of the Esna Formation is invariably low $(0 \%-0.2 \%)$, whereas the black shales of the PETM record a peak of TOC $(1.5 \%-2.7 \%)$. Also the TOC content in the Dakhla Formation ranges between $0.1 \%$ and $0.3 \%$, and is similar to the outcrop values of El Kammar and El Kammar (1996), whereas the Danian/ Selandian black shale bed yields between $0.75 \%$ and $2.0 \%$ TOC. Considering that there is almost a complete loss of TOC due to weathering in Eastern Desert outcrops (El Kammar and El Kammar, 1996), we argue that the TOC contents measured by Speijer and Wagner (2002) and Speijer (2003) in outcrop samples are probably grossly underestimated. Speijer and Wagner (2002) could not exclude weathering as a cause of the low TOC values and the absence of organic dinoflagellate cysts, but they instead favored burial effects. The data of El Kammar and El Kammar (1996) demonstrate that weathering is more likely after all. Considering the amount of combusted organic carbon in the studied sediments and the conversion of all pyrite into iron-oxides, it is likely that this had an influence on the amount of carbonate and thus on the foraminiferal composition. The amount of gypsum veins in the studied marls provides another indication of the intensity of weathering as the gypsum is the byproduct of pyrite weathering and dissolution of $\mathrm{CaCO}_{3}$.

Indeed, the faunal composition also is indicative of different levels of dissolution. In the marls below the PETM of most of the studied sections (Dababiya, Aweina, Qreiya, and Nukhl), high numbers of Subbotina are often associated with large numbers of oxidized pyritic burrows and concretions. In addition, the P/B ratio, PFNs, and the carbonate content are generally lower than in the marls above the PETM. For instance, it is striking that the highest number of Subbotina is recorded at Qreiya, associated 
with the extreme low $\mathrm{PFN}$ and $\mathrm{P} / \mathrm{B}$ ratio. We suggest that all these features together are an index of dissolution, which in general seems to have been more severe before the PETM than after.

Therefore, deep weathering might be the principal factor responsible for dissolution in the marls below the PETM. However, we do not rule out that metabolic consumption of the organic carbon from benthic organisms also contributed to this pattern. Conversely, we could also conclude that originally there may have been less organic carbon in P5c sediments. However, not all localities seem to be affected by this phenomenon. For instance, at Duwi the percentage of Subbotina is generally lower than at the other localities and the carbonate content higher. Although these differences may primarily relate to the shallower setting, it could also be argued that the deposits at Duwi were less prone to weathering than in the Nile Valley. At Qurtayssiat, weathering also seems to have strongly affected the samples of Subzone P5b, as indicated by lower numbers of Acarinina, increased numbers of Subbotina, and altogether extremely low numbers of planktic foraminifera.

In the uppermost Subzone P5c, Subbotina increases again and Morozovella decreases. Because P/B ratios, PFNs, and carbonate content are generally high, we assume that, in this case, the increased numbers of Subbotina represent a primary signal. This change in the planktic assemblage coincides with the termination of the PETM, so it may point to a termination of the extreme warming phase (Berggren and Ouda, 2003). However, superimposed on this general trend, high numbers of Subbotina are still related to lower P/B and PFN at certain levels, suggesting that probably dissolution occurred.

In view of these considerations, we stress that assessments of foraminiferal assemblages must take into account that high numbers of Subbotina might be an artifact from differential dissolution, and are not necessarily related to ecological factors such as cooling. A combination of $\mathrm{P} / \mathrm{B}$ ratios, PFNs, and carbonate content represents a good tool to discern whether increased Subbotina reflects a primary signal or not.

\section{Response of Planktic Foraminiferal Assemblages to the PETM}

In Zone P5, at each locality, Subbotina, Acarinina, and Morozovella are the major components of the planktic assemblages, whereas Igorina, Parasubbotina, and Globanomalina constitute just minor parts. The depth gradient ranging from middle neritic to upper bathyal deposits is not clearly expressed in a corresponding increase in $\mathrm{P} / \mathrm{B}$ ratios from shallow to deep as could be anticipated from the basis of the relationship between modern P/B ratios and water depth (Van der Zwaan et al., 1990). One reason for this may be the configuration of relatively broad Paleogene shelves compared to those of today; another is that partial dissolution strongly overprints the $\mathrm{P} / \mathrm{B}$ ratios. Despite this dissolution, it is possible to reconstruct general patterns of water-column conditions. Before the PETM, well-diversified planktic assemblages dominated by Subbotina, Acarinina, and
Morozovella are indicative of a stratified and well-oxygenated water column. The scarcity of Chiloguembelina, considered to be a low-oxygen thermocline dweller (Premoli Silva and Boersma, 1988; Boersma and Premoli Silva, 1989), supports this view. At Nukhl, higher numbers of Globanomalina are in agreement with the deeper setting of this locality and with colder water compared to the shallower localities. In contrast, at the shallowest Duwi site, the higher abundance of surface dwellers indicates a preference of these taxa for shallower and warmer conditions. In particular, increased numbers of Morozovella in the uppermost Subzone P5a are indicative of higher sea-surface temperatures (i.e., Norris, 1996; Berggren and Norris, 1997; Quillévéré and Norris, 2003).

A major change in the assemblages occurs in the early to middle PETM. The DQB2-3 beds and their equivalents contain oligotaxic assemblages, dominated by generally poorly preserved Acarinina, suggesting high levels of environmental stress in the water column. In particular, the multichambered variety of Acarinina sibaiyaensis is the most common species. A. sibaiyaensis and A. africana are also present, but very rare. Morozovella is almost completely absent during this interval, except for M. allisonensis, which, like A. multicamerata, seemed to have evolved suddenly. In addition, the impoverishment of the thermocline dwellers (Subbotina and Parasubbotina) and the oligotaxic calcareous benthic foraminifera assemblages (Speijer et al., 1996b; Speijer and Wagner, 2002) suggest intensification and vertical expansion of the regional Oxygen Minimum Zone (OMZ).

Above DQB3 and correlative beds (Subzone P5c) the number of Acarinina gradually decreases and the population becomes more diversified. In particular, various Acarinina species are present (i.e., A. sibaiyaensis, A. africana, A coalingensis, A. soldadoensis). All other genera slowly increase again; in particular, Morozovella completely recovers in numbers and in species diversity. Whereas M. allisonensis disappears, the M. velascoensis and $M$. subbotinae groups return to become the most dominant taxa. Such diversified assemblages combined with an increased number of planktic foraminifera indicate recovery of water-column conditions after the PETM perturbation.

Eutrophy versus oligotrophy during the PETM is still an open debate. It seems that oligotrophy characterized large parts of the deep ocean (Kelly et al., 1996b; Bralower, 2002), whereas along continental margins high-nutrient environments developed (Speijer et al., 1996b, 1997; Schmitz et al., 1997b; Crouch et al., 2001; Speijer and Wagner, 2002; Gavrilov et al., 2003). Surprisingly though, the response of planktic foraminiferal assemblages to the climatic perturbation is similar in both settings. Acarinina dominates the planktic assemblages in the open ocean (Kelly et al., 1996b, 1998; Kelly, 2002) and in deep and shallow Tethyan basins (Arenillas and Molina, 1997; Schmitz et al., 1997a; Lu et al., 1998; Arenillas et al., 1999; Molina et al., 1999; Pardo et al., 1999; Obaidalla, 2000; Berggren and Ouda, 2003; Ouda, 2003). Various authors (Kelly et al., 1996b, 1998; Arenillas and Molina, 1997; Kelly, 2002) explain this increase as a response to oligotrophic conditions during the PETM, where photosymbiosis 
may facilitate Acarinina to thrive in low-nutrient waters. However, other proxies, such as benthic foraminifera (Speijer et al., 1996b; Speijer and Schmitz, 1998; Thomas et al., 2000), calcareous nannofossils (Monechi et al., 2000), siliceous plankton and organic dinocysts (Benjamini and Sheva, 1992; Crouch et al., 2001; Egger et al., 2003), barium, phosphate, clay minerals, and TOC records (Schmitz et al., 1997b; Bains et al., 2000; Bolle et al., 2000; Schmitz, 2000; Speijer and Wagner, 2002), rather indicate eutrophic conditions, related to increased upwelling and/or weathering and runoff, particularly in the Tethyan area. For instance, Bolle et al. (2000) suggested that in the southern Tethys, humid and warm conditions in the hinterland enhanced runoff, supplying plenty of nutrients to the water column, to prevent extreme oligotrophy in the basin. In addition, Speijer and Wagner (2002) proposed a paleoceanographic model for this area, suggesting that an inflow of less-oxygenated intermediate water into the epicontinental circulation, combined with intensified upwelling, resulted in severe anoxia on the seafloor. This process resulted in an expanded OMZ and led to the suppression of the thermocline dwellers, such as subbotinids.

Although low productivity on the southern Tethyan margin is an unrealistic scenario, we believe that oligotrophy alone cannot be the primary factor controlling the dominance of Acarinina. Clearly, the trophic strategy or strategies of this group need to be investigated more closely. As pointed out by Houston and Huber (1998), the role of photosymbionts in modifying stable isotopic values is not fully understood in living planktic foraminifera; therefore, the application of stable isotopes to discriminate symbiotic and asymbiotic taxa in the fossil records is full of uncertainties and suppositions. Additionally, we believe that the relationship between planktic foraminifera and their symbionts during the Paleocene is more intricate than generally asserted; however, it probably represents the key to demystifying the success of Acarinina and the suppression of Morozovella at the PETM. It is well accepted that Morozovella and Acarinina share similar ecological preferences: they supposedly inhabited the mixed layer and carried algal symbionts (Pearson et al., 1993; D’Hondt et al., 1994; Kelly et al., 1996a; Norris, 1996). However, among Acarinina different species preferred different habitats within the mixed layer. For instance, the low-trochospiral early species of Acarinina (prior to 57.0 Ma) probably lived in the deeper, cooler, and more mesotrophic part of the mixed layer (Quillévéré and Norris, 2003). Additionally, Corfield and Norris (1998) suggested that significant carbon isotope differences may exist between different clades of Morozovella; for instance $M$. subbotinae occupied a slightly deeper, cooler, and more mesotrophic habitat than $M$. velascoensis (Quillévéré and Norris, 2003). Therefore, the $M$. subbotinae lineage and early species of Acarinina seem to have shared a similar habitat (Olsson et al., 1999; Quillévéré and Norris, 2003). Moreover, oxygen isotopic values indicate that $M$. allisonensis and a multichambered variety of $A$. sibaiyaensis encroached into deeper water during the PETM Kelly et al. (1996b, 1998). We consider it highly relevant that during the PETM, the population of Acarinina is composed mainly of low-trochospiral specimens (e.g., A. multicam- erata) with higher oxygen isotopic values, more similar to early Acarinina species. Similarly, at the Danian-Selandian transition in the same area, we observe a bloom of low-trochospiral Acarinina during the "Neo-duwi event" (Guasti, 2005, Chap. 4), in relation to increased runoff. Also in the Ypresian of the northern Tethyan margin, a peak of Acarinina is associated with sapropelic deposits and related to increased productivity (Oberhänsli and Beniamovskii, 2000). From these examples, we conclude that recorded peaks of Acarinina are particularly connected to increased primary productivity in the Tethyan area during the lower Paleogene. Also, Kelly et al. (2005) described a peak of A. subsphaerica at Site 690 (Weddell Sea, near Antarctica) in connection to increased continental weathering/runoff, a relationship that disagrees with the supposed affinity of this taxon for oligotrophy.

The importance of the partnership between planktic foraminifera and photosymbionts is amply documented for extant (i.e., Hemleben et al., 1989) and fossil taxa. An impairment of this relationship has been suggested as a cause for the extinction of certain taxa. For instance, Kelly et al. (2001) suggested that a progressive deterioration of symbiosis led to the gradual extinction of Morozovella velascoensis. Additionally, during the late middle Eocene, the extinction of the whole Morozovella lineage seems to be related to increased surface-water productivity and the deterioration of photosymbiotic partnership with algae (Wade, 2004).

In the modern ocean, several species of planktic foraminifera are characterized by symbiotic associations. For instance, the endosymbiont of Orbulina universa, Globigerinoides ruber, and G. sacculifer is the dinoflagellate Gymnodinium béii (Gast and Caron, 1996; Rink et al., 1998; Wolf-Gladrow et al., 1999), whereas Globigerinella aequilateralis, Globigerina cristata, and G. falconensis host symbiotic chrysophycophytes (Rink et al., 1998). The amount of light availability plays an important role in the abundance and distribution of symbiont-bearing planktic foraminifera. In the northern California Current, for instance, symbiotic species are more abundant in less turbid (and nutrientpoor) offshore waters, whereas asymbiotic species dominate in high-turbidity (and nutrient-rich) waters close to the coast (Ortiz et al., 1995). However, symbiotic taxa can also reach high abundance in nutrient-rich waters where turbidity is low and availability of light is high (Ortiz et al., 1995). Furthermore, in the Caribbean Basin increased abundance of Globigerinoides ruber is associated with enhanced primary productivity (Schmuker and Schiebel, 2002). Hence, high numbers of symbiotic planktic foraminifera do not point exclusively to oligotrophic conditions; instead light availability is often the determining factor.

We are aware that it is arduous to demonstrate analogies of host-symbiont relationships between extant and Paleocene planktic foraminifera. However, we aim to point out here that oversimplified concepts of trophic strategies of Paleocene taxa are currently inadequate to explain the distributional patterns associated with the PETM and other transient events. We assume that trophic strategies and relationships with symbionts were also complex among Paleocene planktic foraminifera. This is difficult to investigate but should not be excluded a priori. We could speculate, for example, 
that Morozovella and Acarinina might have hosted different symbionts. As with bleaching in marine environments, we speculate that the relationship between Morozovella and its symbionts may have been suppressed at low-middle latitudes during the PETM, in response to environmental stress conditions, including high seasurface temperature. By hosting different symbionts (or having the capability of changing symbionts), low-trochospiral Acarinina may have been better adapted to these conditions. Hence, a mechanism for preferentially eliminating symbionts might have been the major factor controlling the suppression of Morozovella during the PETM. As a consequence, Acarinina could also successfully dominate the oligotrophic open ocean.

We cannot exclude a change in the structure of water masses from having played a role in this faunal change; however, such a scenario on a global scale seems unrealistic to us.

Clearly, our ecological inferences are speculative and need further evaluation, but they underscore that the ecology of Paleocene planktic foraminifera is still poorly understood and that the relationships between foraminiferal distributions and biotic and physicochemical parameters, and between the surface dwellers with their symbionts, are probably much more complex than currently envisaged.

\section{CONCLUSIONS}

Irrespective of their paleobathymetric positions, the studied sections in the Middle East are characterized by similar planktic foraminiferal assemblages in planktic foraminifera Zone P5. Within this zone, changes in the assemblages recorded paleoclimatic and paleoceanographic variations, in particular connected to the hyperthermal event at the Paleocene-Eocene boundary:

- In the marls below the PETM (Subzone P5a), the planktic foraminiferal assemblages are affected by dissolution, indicated by high numbers of Subbotina, fluctuating P/B ratios, and lower numbers of planktic foraminifera per gram of sediment. We stress that assessments of foraminiferal assemblages must take into account that high numbers of Subbotina may be an artifact from differential dissolution, and are not necessarily related to ecological factors such as cooling. A combination of $\mathrm{P} / \mathrm{B}$ ratios, PFNs, and carbonate content represents a good tool to discern whether an increase of Subbotina reflects a primary signal or not.

- The relatively well-diversified planktic assemblages in Subzone P5a are replaced by an oligotaxic Acarininadominated assemblage in response to environmental stress during the PETM. Because biotic and geochemical proxies indicate increased nutrient supply into the basin, due to upwelling and/or enhanced runoff, we argue that the Acarinina peak is not indicative of oligotrophic conditions. Instead, we postulate that (mainly low-trochospiral) Acarinina could have been better adapted to thrive in stressful surface water conditions than Morozovella, because it may have hosted different symbionts.

\section{ACKNOWLEDGMENTS}

Christian Dupuis is thanked for providing samples of Dababiya. We are grateful to Dick Kroon, Jan Smit, and Martin van Breukelen for enabling stable isotope and carbonate measurements in Amsterdam. Saskia Kars and Karl-Heinz Baumann are thanked for help in taking SEM pictures in Amsterdam and in Bremen, respectively. Ralf Schiebel is kindly thanked for suggestions and discussions on ecology of extant planktic foraminifera. Eliana Fornaciari is thanked for nannofossil analysis of Gebel Qurtayssiat. E.G. warmly thanks Jochen Kuss for logistic support, and Claudia Agnini and Christian Scheibner for fruitful discussions on the PETM. Thoughtful suggestions from Estoquio Molina and an anonymous reviewer greatly improved the manuscript.

This project was supported by the Deutsche Forschungsgemeinschaft (DFG) within the European Graduate College "Proxies in Earth History."

\section{REFERENCES CITED}

Alegret, L., Ortiz, S., Arenillas, I., and Molina, E., 2005, Paleoenvironmental turnover across the Paleocene/Eocene boundary at the stratotype section in Dababiya (Egypt) based on benthic foraminifera: Terra Nova, v. 17, p. 526-536.

Arenillas, I., and Molina, E., 1997, Análisis cuantitativo de los foraminíferos planctónicos del Paleoceno de Caravaca (Cordillera Bética): Bioestratigrafía y evolución de las asociaciones: Revista Española de Micropaleontología, v. 12, p. 207-232.

Arenillas, I., Molina, E., and Schmitz, B., 1999, Planktic foraminiferal and $\delta^{13} \mathrm{C}$ isotopic changes across the Paleocene/Eocene boundary at Possagno (Italy): International Journal of Earth Sciences, v. 88, p. 352-364, doi: $10.1007 / \mathrm{s} 005310050270$.

Aubry, M.-P., 1998, Early Paleogene calcareous nannoplankton evolution: A tale of climatic amelioration, in Aubry, M.-P., Lucas, S., and Berggren, W.A., eds., Late Paleocene-early Eocene climatic evolution and biotic events in the marine and terrestrial records: New York, Columbia University Press, p. 158-203.

Aubry, M.-P., Berggren, W.A., Stott, L.D., and Sinha, A., 1996, The upper Paleocene-lower Eocene stratigraphic record and the Paleocene-Eocene boundary carbon excursion: Implications for geochronology, in Knox, R.W.O'B., Corfield, R., Dunay, R.E., eds., Correlation of the early Paleogene in Northwest Europe: Geological Society [London] Special Publication 101, p. 353-380.

Bains, S., Norris, R.D., Corfield, R.M., and Faul, K.L., 2000, Termination of global warmth at the Paleocene/Eocene boundary through productivity feedback: Nature, v. 407, p. 171-174, doi: 10.1038/35025035.

Bé, A.W.H., 1977, An ecological, zoogeographic and taxonomic review of recent planktonic foraminifera, in Ramsay, A.T.S., ed., Oceanic micropaleontology, Volume 1: London, Academic Press, p. 1-100.

Benjamini, C., and Sheva, B., 1992, The Paleocene-Eocene boundary in Israel-A candidate for the boundary stratotype: Neues Jahrbuch für Geologie und Paläontologie, Abhandlungen, v. 186, p. 49-61.

Berger, W.H., 1970, Planktonic foraminifera: Selective solution and the lysocline: Marine Geology, v. 8, p. 111-138, doi: 10.1016/0025-3227 (70)90001-0.

Berggren, W.A., and Norris, R.D., 1997, Biostratigraphy, phylogeny and systematics of Paleocene trochospiral planktic foraminifera: Micropaleontology, v. 43, p. 1-116, doi: 10.2307/1485988.

Berggren, W.A., and Ouda, K., 2003, Upper Paleocene-lower Eocene planktonic foraminiferal biostratigraphy of the Dababiya section, Upper Nile Valley (Egypt), in Ouda, K., and Aubry, M.-P., The upper Paleocene-lower Eocene of the upper Nile Valley, Part 1, Stratigraphy: Micropaleontology, v. 49, suppl. 1, p. 61-92, doi: 10.2113/49.Suppl_1.61.

Berggren, W.A., Kent, D.V., Swisher, C.C., III, and Aubry, M.P., 1995, A revised Cenozoic geochronology and chronostratigraphy, in Berggren, 
W.A., Kent, D.V., Aubry, M.-P., and Hardenbol, J., eds., Geochronology, time scales and global stratigraphic correlation: SEPM (Society for Sedimentary Geology) Special Publication 54, p. 129-212.

Berggren, W.A., Aubry, M.-P., van Fossen, M., Kent, D.V., Norris, R.D., and Quillévéré, F., 2000, Integrated Paleocene calcareous plankton magnetobiochronology and stable isotope stratigraphy: DSDP Site 384 (NW Atlantic Ocean): Palaeogeography, Palaeoclimatology, Palaeoecology, v. 159, p. 1-51, doi: 10.1016/S0031-0182(00)00031-6.

Berggren, W.A., Ouda, K., Ahmed, E.A., Obaidalla, N., and Saad, K., 2003, Upper Paleocene-lower Eocene planktonic foraminiferal biostratigraphy of the Wadi Abu Ghurra section, Upper Nile Valley (Egypt), in Ouda, K., and Aubry, M.-P., eds., The upper Paleocene-lower Eocene of the upper Nile Valley, Part 1, Stratigraphy: Micropaleontology, v. 49, suppl. 1, p. $167-178$.

Boersma, A., and Premoli Silva, I., 1983, Paleocene planktonic foraminiferal biogeography and the paleoceanography of the Atlantic Ocean: Micropaleontology, v. 29, p. 355-381, doi: 10.2307/1485514.

Boersma, A., and Premoli Silva, I., 1989, Atlantic Paleogene biserial heterohelicid foraminifera and oxygen minima: Paleoceanography, v. 4, p. $271-$ 286.

Bolle, M.-P., Tantawy, A.A., Pardo, A., Adatte, T., Burns, S., and Kassab, A., 2000, Climatic and environmental changes documented in the upper Paleocene to lower Eocene of Egypt: Eclogae Geologicae Helvetiae, v. 93, p. 33-51.

Bralower, T.J., 2002, Evidence of surface water oligotrophy during the Paleocene-Eocene thermal maximum: nannofossil assemblage data from Ocean Drilling Program Site 690, Maud Rise, Weddell Sea: Paleoceanography, v. 17 , p. $1-12$.

Charisi, S.D., and Schmitz, B., 1995, Stable $\left(\delta^{13} \mathrm{C}, \delta^{18} \mathrm{O}\right)$ and strontium $\left({ }^{87} \mathrm{Sr} /{ }^{86} \mathrm{Sr}\right)$ isotopes through the Paleocene at Gebel Aweina, eastern Tethyan region: Palaeogeography, Palaeoclimatology, Palaeoecology, v. 116, p. 103-129, doi: 10.1016/0031-0182(94)00090-U.

Charisi, S.D., and Schmitz, B., 1998, Paleocene to early Eocene paleoceanography of the Middle East; the $\delta^{13} \mathrm{C}$ and $\delta^{18} \mathrm{O}$ isotopes from foraminiferal calcite: Paleoceanography, v. 13, p. 106-118, doi: 10.1029/97PA02585.

Clyde, W.C., and Gingerich, P.D., 1998, Mammalian community response to the latest Paleocene thermal maximum: An isotaphonomic study in the northern Bighorn Basin, Wyoming: Geology, v. 26, p. 1011-1014, doi: 10.1130/0091-7613(1998)026<1011:MCRTTL>2.3.CO;2.

Corfield, R.M., and Norris, R.D., 1998, The oxygen and carbon isotopic context of the Paleocene/Eocene epoch boundary, in Aubry, M.-P., Lucas, S., and Berggren, W.A., eds., Late Paleocene-early Eocene climate and biotic events in the marine and terrestrial records: New York, Columbia University Press, p. 124-137.

Crouch, E.M., Heilmann-Clausen, C., Brinkhuis, H., Morgans, H.E.G., Rogers, K.M., Egger, H., and Schmitz, B., 2001, Global dinoflagellate event associated with the late Paleocene thermal maximum: Geology, v. 29, p. 315318, doi: 10.1130/0091-7613(2001)029<0315:GDEAWT>2.0.CO;2.

D'Hondt, S., Zachos, J.C., and Schultz, G., 1994, Stable isotopic signal and photosymbiosis in late Paleocene planktic foraminifera: Paleobiology, v. 30, p. 391-406.

Dickens, G.R., 2001, Carbon addition and removal during the Late Paleocene Thermal Maximum: Basic theory with a preliminary treatment of the isotope record at ODP Site 1051, Blake Nose, in Kroon, D., Norris, R.D., and Klaus, A., eds., Western North Atlantic Paleogene and Cretaceous palaeoceanography: Geological Society [London] Special Publication 183 , p. 293-305.

Dickens, G.R., O’Neil, J.R., Rea, D.K., and Owen, R.M., 1995, Dissociation of oceanic methane hydrate as a cause of the carbon isotope excursion at the end of the Paleocene: Paleoceanography, v. 10, p. 965-971, doi: 10.1029/95PA02087.

Dittert, N., Baumann, K.-H., Bickert, T., Henrich, R., Huber, R., Kinkel, H., and Meggers, H., 1999, Carbonate dissolution in the deep-sea: Methods, quantification and paleoceanographic application, in Fischer, G., and Wefer, G., eds., Use of proxies in paleoceanography: Examples from the south Atlantic: Berlin, Springer, p. 255-284.

Douglas, R., and Woodruff, F., 1981, Deep sea benthic foraminifera, in Emiliani, C., ed., The sea, Volume 7, The oceanic lithosphere: New York, Wiley-Interscience, p. 1233-1327.

Dupuis, C., Aubry, M.-P., Steurbaut, E., Berggren, W.A., Ouda, K., Magioncalda, R., Cramer, B.S., Kent, D.V., Speijer, R.P., and Heilmann-Clausen, C., 2003, The Dababiya Quarry section; lithostratigraphy, clay mineral- ogy, geochemistry and paleontology, in Ouda, K., and Aubry, M.-P., eds., The upper Paleocene-lower Eocene of the upper Nile Valley, Part 1, Stratigraphy: Micropaleontology, v. 49, suppl. 1, p. 41-59.

Egger, H., Fenner, J., Heilmann-Clausen, C., Rögl, F., Sachsenhofer, R.F., and Schmitz, B., 2003, Paleoproductivity of the north-western Tethyan margin (Anthering section, Austria) across the Paleocene-Eocene transition, in Wing, S.L., Gingerich, P.D, Schmitz, B., and Thomas, E., eds., Causes and consequences of globally warm climates of the Paleogene: Geological Society of America Special Paper 369, p. 133-146.

Eldholm, O., and Thomas, E., 1993, Environmental impact of volcanic margin formation: Earth and Planetary Sciences Letters, v. 117, p. 319-329, doi: 10.1016/0012-821X(93)90087-P.

Elewa, A.M.T., and Morsi, A.M., 2004, Palaeobiotope analysis and palaeoenvironmental reconstruction of the Palaeocene-early Eocene ostracodes from east-central Sinai, Egypt, in Beaudoin, A.B., and Head, M.J., eds., The palynology and micropalaeontology of boundaries: Geological Society [London] Special Publication 230, p. 293-308.

El Kammar, A.M., and El Kammar, M.M., Jr., 1996, Potentiality of chemical weathering under arid conditions of black shales from Egypt: Journal of Arid Environments, v. 33, p. 179-199, doi: 10.1006/jare.1996.0055.

El-Naggar, 1966, Stratigraphy and planktonic foraminifera of the upper Cretaceous-lower Tertiary succession in the Esna-Idfu region, Nile Valley, U. A. R., Egypt: London, Bulletin of the British Museum (Natural History) Geology Supplement, v. 2, p. 1-291.

Ernst, S.R., Guasti, E., Dupuis, C., and Speijer, R.P., 2006, Environmental perturbation in the southern Tethys across the Paleocene/Eocene boundary (Dababiya, Egypt): Foraminiferal and clay mineral records: Marine Micropaleontology, v. 60, p. 89-111.

Freiwald, A., 1995, Bacteria-induced carbonate degradation: A taphonomic case study of Cibicides lobatulus from a high-boreal carbonate setting: Palaios, v. 10, p. 337-346.

Garfunkel, Z., and Ben-Avraham, Z., 1996, The structure of the Dead Sea basin: Tectonophysics, v. 266, p. 155-176, doi: 10.1016/S0040-1951(96) 00188-6.

Gast, R.J., and Caron, D.A., 1996, Molecular phylogeny of symbiotic dinoflagellates from planktonic foraminifera and radiolarian: Molecular Biology and Evolution, v. 13, p. 1192-1996.

Gavrilov, Y.O., Shcherbinina, E.A., and Oberhänsli, H., 2003, PaleoceneEocene boundary events in the northeastern Peri-Tethys, in Wing, S.L., Gingerich, P.D, Schmitz, B., and Thomas, E., eds., Causes and consequences of globally warm climates of the Paleogene: Geological Society of America Special Paper 369, p. 147-168.

Guasti, E., 2005, Early Paleogene environmental turnover in the Southern Tethys as recorded by foraminiferal and organic-walled dinoflagellate cysts assemblages [Ph.D. thesis]: Berichte aus dem Fachbereich Geowissenschaften der Universität Bremen, v. 241, 203 p.

Hemleben, C., Spindler, M., and Anderson, O.R., 1989, Modern planktonic foraminifera: New York, Springer, $363 \mathrm{p}$.

Hodgkinson, R.L., 1991, Microfossil processing; a damage report: Micropaleontology, v. 37, p. 320-326, doi: 10.2307/1485894.

Houston, R.M., and Huber, B.T., 1998, Evidence of photosymbiosis in fossil taxa? Ontogenetic stable isotope trends in some Late Cretaceous planktonic foraminifera: Marine Micropaleontology, v. 34, p. 29-46, doi: 10.1016/S0377-8398(97)00038-8.

Jorissen, F.J., and Wittling, I., 1999, Ecological evidence from live-dead comparisons of benthic foraminiferal faunas off Cape Blanc (Northwest Africa): Palaeogeography, Palaeoclimatology, Palaeoecology, v. 149, p. 151-170, doi: 10.1016/S0031-0182(98)00198-9.

Kelly, C.D., 2002, Response of Antarctic (ODP Site 690) planktonic foraminifera to the Paleocene-Eocene thermal maximum: Faunal evidence for ocean/climate change: Paleoceanography, v. 17, p. 1-13, doi: 10.1029/ 2002PA000761.

Kelly, C.D., Arnold, A.J., and Parker, W.C., 1996a, Paedomorphosis and the origin of the Paleogene planktonic foraminiferal genus Morozovella: Paleobiology, v. 22, p. 266-281.

Kelly, C.D., Bralower, T.J., Zachos, J.C., Premoli Silva, I., and Thomas, E., 1996b, Rapid diversification of planktonic foraminifera in the tropical Pacific (ODP Site 865) during the late Paleocene thermal maximum: Geology, v. 24, p. 423-426, doi: 10.1130/0091-7613(1996)024<0423: RDOPFI>2.3.CO;2.

Kelly, C.D., Bralower, T.J., and Zachos, J.C., 1998, Evolutionary consequences of the latest Paleocene thermal maximum for tropical planktonic forami- 
nifera: Palaeogeography, Palaeoclimatology, Palaeoecology, v. 141, p. 139-161, doi: 10.1016/S0031-0182(98)00017-0.

Kelly, C.D., Bralower, T.J., and Zachos, J.C., 2001, On the demise of the early Paleogene Morozovella velascoensis lineage: Terminal progenesis in the planktonic foraminifera: Palaios, v. 16, p. 507-523.

Kelly, C.D., Zachos, J.C., Bralower, T.J., and Schellenberg, S.A., 2005, Enhanced terrestrial weathering/runoff and surface ocean carbonate production during the recovery stages of the Paleocene-Eocene thermal maximum: Paleoceanography, v. 20, p. PA4023, doi: 10.1029/2005PA001163, doi: 10.1029/2005PA001163.

Kennett, J.P., and Stott, L.D., 1991, Abrupt deep-sea warming, paleoceanographic changes and benthic extinctions at the end of the Paleocene: Nature, v. 353, p. 225-229, doi: 10.1038/353225a0.

Kent, D.V., Cramer, B.S., Lanci, L., Wang, D., Wright, J.D., and Van der Voo, R., 2003, A case for a comet impact trigger for the Paleocene/ Eocene thermal maximum and carbon isotope excursion: Earth and Planetary Science Letters, v. 211, p. 13-26, doi: 10.1016/S0012821X(03)00188-2.

Knox, R.W.O.B., Aubry, M.-P., Berggren, W.A., Dupuis, C., Ouda, K., Magioncalda, R., and Soliman, M., 2003, The Qreiya section at Gebel Abu Had: Lithostratigraphy, clay mineralogy, geochemistry and biostratigraphy, in Ouda, K., and Aubry, M.-P., eds., The upper Paleocene-lower Eocene of the upper Nile Valley, Part 1, Stratigraphy: Micropaleontology, v. 49, suppl. 1, p. 93-104.

Koch, P.L., Zachos, J.C., and Dettman, D.L., 1995, Stable isotope stratigraphy and paleoclimatology of the Paleogene Bighorn Basin (Wyoming, USA): Palaeogeography, Palaeoclimatology, Palaeoecology, v. 115, p. 61-89, doi: 10.1016/0031-0182(94)00107-J.

Loubere, P., and Gary, A.C., 1990, Taphonomic process and species microhabitats in the living to fossil assemblage transition of deeper water benthic foraminifera: Palaios, v. 5, p. 375-381.

Lu, G., Adatte, T., Keller, G., and Ortiz, N., 1998, Abrupt climatic, oceanographic and ecologic changes near the Paleocene-Eocene transition in the deep Tethys basin: The Alamedilla section, southern Spain: Eclogae Geologicae Helvetiae, v. 91, p. 293-306.

Martin, R., 1993, Time and taphonomy: Actualistic evidence for time averaging of benthic foraminiferal assemblages, in Kidwell, S.M, and Behrensmeyer, A.K, eds., Taphonomic approaches to time resolution in fossil assemblages: Knoxville, Tennessee, Paleontological Society, Short Courses in Paleontology, no. 6, p. 34-56.

Masri, M., 1963, Report on the geology of the Amman-Zerqa area: Amman, Jordan, Central Water Authority, $74 \mathrm{p}$.

Molina, E., Arenillas, I., and Pardo, A., 1999, High resolution planktic foraminiferal biostratigraphy and correlation across the Paleocene/Eocene boundary in the Tethys: Bulletin de la Société Géologique de France, v. 170 , p. 521-530.

Monechi, S., Angori, E., and Speijer, R.P., 2000, Upper Paleocene biostratigraphy in the Mediterranean region: Zonal markers, diachronism, and preservational problems, in Andreasson, F.P., Schmitz, B., and Thompson, E.I., eds., Early Paleogene warm climates and biosphere dynamics: GFF, v. 122, p. 108-110.

Murray, J.W., and Alve, E., 1999, Taphonomic experiments on marginal marine foraminiferal assemblages: How much ecological information is preserved?: Palaeogeography, Palaeoclimatology, Palaeoecology, v. 149, p. 183-197, doi: 10.1016/S0031-0182(98)00200-4.

Norris, R.D., 1996, Symbiosis as an evolutionary innovation in the radiation of Paleocene planktic foraminifera: Paleobiology, v. 22, p. 461-480.

Norris, R.D., and Nunes, F., 2004, Productivity maximum across the PaleoceneEocene boundary supported by faunal evidence: Eighth International Conference on Paleoceanography (ICP VIII), Biarritz, France, September 2004, Abstracts, p. 48.

Obaidalla, N.A., 2000, Planktonic foraminiferal biostratigraphy and faunal turnover events during the Late Cretaceous-early Tertiary along the Rea Sea coast, Egypt: Journal of African Earth Sciences, v. 31, p. 571-595, doi: 10.1016/S0899-5362(00)80008-1.

Oberhänsli, H., and Beniamovskii, V.N., 2000, Dysoxic bottom water events in the pero-Tethys during the late Ypresian: A result of changes in the evaporation/precipitation balance in adjacent continental regions, in Andreasson, F.P., Schmitz, B., and Thompson, E.I., eds., Early Paleogene warm climates and biosphere dynamics: GFF, v. 122, p. 121-123.

Okada, H., and Bukry, D., 1980, Supplementary modification and introduction of code numbers to the low-latitude coccolith biostrati- graphic zonation: Marine Micropaleontology, v. 5, p. 321-325, doi: 10.1016/0377-8398(80)90016-X.

Olsson, R.K., Hemleben, C., Berggren, W.A., and Huber, B.T., 1999, Atlas of Paleocene planktonic foraminifera: Smithsonian Contributions to Paleobiology, v. 85,252 p.

Oreshkina, T.V., and Oberhänsli, H., 2003, Diatom turnover in the early Paleogene diatomite of the Sengiley section, Middle Povolzhie, Russia: A response to the Initial Eocene Thermal Maximum?, in Wing, S.L., Gingerich, P.D, Schmitz, B., and Thomas, E., eds., Causes and consequences of globally warm climates of the Paleogene: Geological Society of America Special Paper 369, p. 169-180.

Ortiz, J.D., Mix, A.C., and Collier, R.W., 1995, Environmental control of living symbiotic and asymbiotic foraminifera of the California Current: Paleoceanography, v. 10, p. 987-1009, doi: 10.1029/95PA02088.

Ouda, K., 2003, The Paleocene/Eocene boundary in Egypt: An overview, in Ouda, K., and Aubry, M.-P., eds., The upper Paleocene-lower Eocene of the upper Nile Valley, Part 1, Stratigraphy: Micropaleontology, v. 49, suppl. 1, p. 15-40, doi: 10.2113/49.Suppl_1.15.

Ouda, K., and Aubry, M.-P., 2003, The upper Paleocene-lower Eocene of the upper Nile Valley, Part 1, Stratigraphy: Micropaleontology, v. 49, suppl. 1, $212 \mathrm{p}$

Ouda, K., and Berggren, W.A., 2003, Biostratigraphic correlation of the Upper Paleocene-Lower Eocene succession in the Upper Nile Valley: A synthesis, in Ouda, K., and Aubry, M.-P., eds., The upper Paleocene-lower Eocene of the upper Nile Valley, Part 1, Stratigraphy: Micropaleontology, v. 49, suppl. 1, p. 179-212.

Ouda, K., Berggren, W.A., and Saad, K., 2003, The Gebel Oweina and Kilabiya sections in the Idfu-Esna area, Upper Nile Valley (Egypt), in Ouda, K., and Aubry, M.-P., eds., The upper Paleocene-lower Eocene of the upper Nile Valley, Part 1, Stratigraphy: Micropaleontology, v. 49, suppl. 1, p. 147-166, doi: 10.2113/49.Suppl_1.147.

Pardo, A., Keller, G., and Oberhänsli, H., 1999, Paleoecologic and paleoceanographic evolution of the Tethyan realm during the Paleocene-Eocene transition: Journal of Foraminiferal Research, v. 29, p. 37-57.

Pearson, P.N., Shackleton, N.J., and Hall, M.A., 1993, Stable isotope paleoecology of middle Eocene planktonic foraminifera and multi-species isotope stratigraphy, DSDP Site 523, South Atlantic: Journal of Foraminiferal Research, v. 23, p. 123-140.

Premoli Silva, I., and Boersma, A., 1988, Atlantic Eocene planktonic foraminiferal historical biogeography and paleohydrographic indices: Palaeogeography, Palaeoclimatology, Palaeoecology, v. 67, p. 315-356, doi: 10.1016/0031-0182(88)90159-9.

Quillévéré, F., and Norris, R.D., 2003, Ecological development of acarininids (planktonic foraminifera) and hydrographic evolution of Paleocene surface waters, in Wing, S.L., Gingerich, P.D, Schmitz, B., and Thomas, E., eds., Causes and consequences of globally warm climates of the Paleogene: Geological Society of America Special Paper 369, p. 223-238.

Rink, S., Kühl, M., Bijma, J., and Spero, H.J., 1998, Microsensor studies of photosynthesis and respiration in the symbiotic foraminifer Orbulina universa: Marine Biology, v. 131, p. 583-595, doi: 10.1007/ s002270050350.

Said, R., 1990, Cenozoic, in Said, R., ed., The geology of Egypt: Rotterdam, A.A. Balkema, p. $451-486$.

Scheibner, C., Marzouk, A.M., and Kuss, J., 2001, Maastrichtian-early Eocene litho-biostratigraphy and palaeogeography of the northern Gulf of Suez region, Egypt: Journal of African Earth Sciences, v. 32, p. 223-255, doi: 10.1016/S0899-5362(01)90005-3.

Scheibner, C., Speijer, R.P., and Marzouk, A.M., 2005, Turnover of larger foraminifera during the Paleocene-Eocene Thermal Maximum and paleoclimatic control on the evolution of platform ecosystems: Geology, v. 33, p. 493-496, doi: 10.1130/G21237.1.

Schmitz, B., 2000, Plankton cooled a greenhouse: Nature, v. 407, p. 143-144, doi: $10.1038 / 35025173$.

Schmitz, B., Speijer, R.P., and Aubry, M.-P., 1996, Latest Paleocene benthic extinction event on the southern Tethyan shelf (Egypt): Foraminiferal stable isotopic $\left(\delta^{13} \mathrm{C}, \delta^{18} \mathrm{O}\right)$ records: Geology, v. 24, p. $347-350$, doi: 10.1130/0091-7613(1996)024<0347:LPBEEO>2.3.CO;2.

Schmitz, B., Asaro, F., Molina, E., Monechi, S., von Salis, K., and Speijer, R.P., 1997a, High-resolution iridium, $\delta^{13} \mathrm{C}, \delta^{18} \mathrm{O}$, foraminifera and nannofossil profiles across the latest Paleocene benthic extinction event at Zumaya, Spain: Palaeogeography, Palaeoclimatology, Palaeoecology, v. 133, p. 49-68, doi: 10.1016/S0031-0182(97)00024-2. 
Schmitz, B., Charisi, S.D., Thompson, E.I., and Speijer, R.P., 1997b, Barium, $\mathrm{SiO}_{2}$ (excess), and $\mathrm{P}_{2} \mathrm{O}_{5}$ as proxies of biological productivity in the Middle East during the Paleocene and the latest Paleocene benthic extinction event: Terra Nova, v. 9, p. 95-99, doi: 10.1111/j.1365-3121.1997. tb00011.x.

Schmuker, B., and Schiebel, R., 2002, Planktic foraminifers and hydrography of the eastern and northern Caribbean Sea: Marine Micropaleontology, v. 46, p. 387-403, doi: 10.1016/S0377-8398(02)00082-8.

Shahar, J., 1994, The Syrian arc system: An overview: Palaeogeography, Palaeoclimatology, Palaeoecology, v. 112, p. 125-142, doi: 10.1016/00310182(94)90137-6.

Soliman, M.F., 2003, Chemostratigraphy of the Paleocene/Eocene (P/E) boundary sediments at Gabal el-Qreiya, Nile Valley, Egypt, in Ouda, K., and Aubry, M.-P., eds., The upper Paleocene-lower Eocene of the upper Nile Valley, Part 1, Stratigraphy: Micropaleontology, v. 49, suppl. 1, p. 123-138.

Speijer, R.P., 1994, The late Paleocene benthic foraminiferal extinction as observed in the middle East: Bulletin de la Société Belge de Géologie, v. 3-4, p. 267-280.

Speijer, R.P., 2003, Danian-Selandian sea-level change and biotic excursion on the southern Tethyan margin (Egypt), in Wing, S.L., Gingerich, P.D., Schmitz, B., and Thomas, E., eds., Causes and consequences of globally warm climates in the early Paleogene, Geological Society of America Special Paper 369, p. 275-290.

Speijer, R.P., and Morsi, A.-M.M., 2002, Ostracode turnover and sea-level changes associated with the Paleocene-Eocene thermal maximum: Geology, v. 30, p. 23-26, doi: 10.1130/0091-7613(2002)030<0023: OTASLC $>2.0 . \mathrm{CO} ; 2$.

Speijer, R.P., and Schmitz, B., 1998, A benthic foraminiferal record of Paleocene sea-level and trophic/redox conditions at Gebel Aweina, Egypt: Palaeogeography, Palaeoclimatology, Palaeoecology, v. 137, p. 79-101, doi: 10.1016/S0031-0182(97)00107-7.

Speijer, R.P., and Van der Zwaan, G.J., 1994, The differential effect of the Paleocene/Eocene boundary event: Extinction and survivorship in shallow to deep water Egyptian benthic foraminiferal assemblages, in Extinction and recovery patterns in benthic foraminiferal paleocommunities across the Cretaceous/Paleogene and Paleocene/Eocene boundaries: Geologica Ultraiectina, v. 124, p. 121-168.

Speijer, R.P., and Wagner, T., 2002, Sea-level changes and black shales associated with the late Paleocene thermal maximum: Organic-geochemical and micropaleontologic evidence from the southern Tethyan margin (EgyptIsrael), in Koeberl, C., and MacLeod, K.G., eds., Catastrophic events and mass extinctions: Impacts and beyond: Geological Society of America Special Paper 356, p. 533-549.

Speijer, R.P., Schmitz, B., Aubry, M.-P., and Charisi, S.D., 1996a, The latest Paleocene benthic extinction event: Punctuated turnover in outer neritic foraminiferal faunas from Gebel Aweina, Egypt: Israel Journal of Earth Sciences, v. 44, p. 207-222.

Speijer, R.P., Van der Zwaan, G.J., and Schmitz, B., 1996b, The impact of Paleocene/Eocene boundary events on middle neritic benthic foraminiferal assemblages from Egypt: Marine Micropaleontology, v. 28, p. 99 132, doi: 10.1016/0377-8398(95)00079-8.

Speijer, R.P., Schmitz, B., and Van der Zwaan, G.J., 1997, Benthic foraminiferal extinction and repopulation in response to latest Paleocene Tethyan anoxia: Geology, v. 25, p. 683-686, doi: 10.1130/0091-7613(1997)025 $<0683$ :BFEARI>2.3.CO;2.
Speijer, R.P., Schmitz, B., and Luger, P., 2000, Stratigraphy of late Paleocene events in the Middle East: Implications for low- to middle-latitude successions and correlations: Geological Society [London] Journal, v. 157, p. $37-47$.

Stoll, H.M., and Bains, S., 2003, Coccolith Sr/Ca records of productivity during the Paleocene-Eocene thermal maximum from the Weddell Sea: Paleoceanography, v. 18, doi: 10.1029/2002PA000875, doi: 10.1029/ 2002PA000875.

Svensen, H., Planke, S., Malthe-Sorenssen, A., Jamtveit, B., Myklebust, R., Rasmussen Eidem, T., and Rey, S.S., 2004, Release of methane from a volcanic basin as a mechanism for initial Eocene global warming: Nature, v. 429 , p. 542-545, doi: 10.1038/nature02566.

Tantawy, A.A., Keller, G., Adatte, T., Stinnesbeck, W., Kassab, A., and Schulte, P., 2001, Maastrichtian to Paleocene depositional environment of the Dakhla Formation, Western Desert, Egypt: Sedimentology, mineralogy, and integrated micro- and macrofossil biostratigraphies: Cretaceous Research, v. 22, p. 795-827, doi: 10.1006/cres.2001.0291.

Tawarados, E.E., 2001, Geology of Egypt and Libya: Rotterdam, A.A. Balkema, $468 \mathrm{p}$.

Thomas, E., 1998, Biogeography of the late Paleocene benthic foraminiferal extinction, in Aubry, M.-P., Lucas, S., and Berggren, W.A., eds., Late Paleocene-early Eocene climatic and biotic events in the marine and terrestrial records: New York, Columbia University Press, p. 214-243.

Thomas, E., Zachos, J.C., and Bralower, T.J., 2000, Deep-sea environments on a warm earth latest Paleocene-early Eocene, in Huber, B.T, MacLeod, K.G., and Wing, S.L., eds., Warm climates in earth history: Cambridge, UK, Cambridge University Press, p. 132-160.

Thompson, E.I., and Schmitz, B., 1997, Barium and the late Paleocene $\delta^{13} \mathrm{C}$ maximum: Evidence of increased marine surface productivity: Paleoceanography, v. 12, p. 239-254, doi: 10.1029/96PA03331.

Tjalsma, R.C., and Lohmann, G.P., 1983, Paleocene-Eocene bathyal and abyssal benthic foraminifera from the Atlantic ocean: Micropaleontology Special Publication 4, p. 90.

Van der Zwaan, G.J., Jorissen, F.J., and de Stigter, H.C., 1990, The depth dependency of planktonic/benthic foraminiferal ratios: Constraints and applications: Marine Geology, v. 95, p. 1-16, doi: 10.1016/0025-3227 (90)90016-D.

Wade, B.S., 2004, Planktonic foraminiferal biostratigraphy and mechanisms in the extinction of Morozovella in the late middle Eocene: Marine Micropaleontology, v. 51, p. 23-38, doi: 10.1016/j.marmicro.2003.09.001.

Wignall, P.B., 1994, Black shales: Oxford, UK, Oxford University Press, Oxford Monographs on Geology and Geophysics, v. 30, 127 p.

Wolf-Gladrow, D.A., Bijma, J., and Zeebe, R.E., 1999, Model simulation of the carbonate chemistry in the microenvironment of symbiont bearing foraminifera: Marine Chemistry, v. 64, p. 181-198, doi: 10.1016/S03044203(98)00074-7.

Youssef, M.M., 2004, The benthonic foraminifera turnover at the Paleocene/ Eocene Thermal Maximum Event (PETM) in the southwestern Nile Valley, Egypt: Neues Jahrbuch für Geologie und Paläontologie, Abhandlungen, v. 234, no. 1-3, p. 261-289.

Zachos, J.C., Lohmann, K.C., Walker, J.C.G., and Wise, S.W., 1993, Abrupt climate change and transient climates during the Paleogene: A marine perspective: Journal of Geology, v. 101, p. 191-213.

Manuscript AccePted By the Society 20 November 2006 
